\title{
Evaluation of Physical and Cooking Characteristics of Five Improved Lima Beans
}

\author{
Kyeremateng Daniel Owusu ${ }^{1}$, Coleman Fred Newman ${ }^{2,}$, Agyare-Gyimah Gabriel $^{2}$ \\ ${ }^{1}$ Department of Food Science and Technology, Methodist University College Ghana, Wenchi, Ghana \\ ${ }^{2}$ Department of Agriculture and Agribusiness, Methodist University College Ghana, Wenchi, Ghana
}

\section{Email address:}

danokyeremateng@gmail.com (Kyeremateng D. O.), colemanf27@yahoo.com (Coleman F. N.), agyaregyimahgabriel@gmail.com (Agyare-Gyimah G.)

${ }^{*}$ Corresponding author

\section{To cite this article:}

Kyeremateng Daniel Owusu, Coleman Fred Newman, Agyare-Gyimah Gabriel. Evaluation of Physical and Cooking Characteristics of Five Improved Lima Beans. World Journal of Food Science and Technology. Vol. 2, No. 2, 2018, pp. 38-43. doi: 10.11648/j.wjfst.20180202.13

Received: May 10, 2018; Accepted: June 4, 2018; Published: July 6, 2018

\begin{abstract}
Phaseolus lunatus commonly known as lima bean is one of the important leguminous crops in the genus phaseolus noted for its nutritional and medicinal properties. However, the current improved varieties released by Crop Research Institute (CRI) have no documental records on their physical and cooking properties. This informed the study to evaluate the physical and cooking characteristics of 5 improved lima beans. The lima beans were obtained from Crop Research Institute, Fumesua-Ghana and analyses on physical and cooking properties were carried out. Seed length ranged from 19.12 to $25.50 \mathrm{~mm}$, breadth from 12.41 to $15.41 \mathrm{~mm}$ with significant differences among the accessions. However, thickness which varied from 5.10 to $6.58 \mathrm{~mm}$ showed no statistical significant difference. The thousand (1000) seed weight significantly varied from 886.00 to $1311.65 \mathrm{~g}$. All the five lima bean accessions belonged to the Andean gene pool or Meso-American large seeded type. Length/breadth \& water uptake ratio, and bulk density were within the range of 1.49 to $1.76,1.15$ to $1.81 \mathrm{~g}$, and 0.59 to $0.62 \mathrm{~g} / \mathrm{ml}$, respectively. The cooking time of all the accessions ranged from $81.00 \mathrm{mins}$ to $91.50 \mathrm{mins}$ with no significant differences. Cooked Length-Breadth and water uptake ratios had minimum and maximum values of 1.39 to 1.78 and 1.15 to 1.31 , respectively. Seed hydration capacity and index had values between 18.98-23.05 g/seed \& 7.14-10.45; swelling capacity ranged between $17.98-20.38 \mathrm{ml} / \mathrm{seed}$ and swelling index recorded values between 3.88-5.10. The physical and cooking properties of legumes are important for the design of equipment necessary for food processing, packaging, post-harvest handling and also for determination of cooking quality. The underutilized legumes have physical and cooking characteristic which make them potentially ideal for commercial cultivation, local food uses and for industrial food processing.
\end{abstract}

Keywords: Phaseolus lunatus, Cooking Characteristics, Sensory Properties

\section{Introduction}

Phaseolus lunatus commonly known as lima bean is one of the important leguminous crops in the genus phaseolus noted for its nutritional and medicinal properties. They are a type of legume native to South American. Lima bean is also underutilized legume grown in Ghana, Nigeria and warmer areas of the World [1]. It has amino acid profile similar to soybean and cowpea [2]. In Ghana and other developing countries, legumes are the second largest sources of human food after cereals. They are the fourth important legume food in Ghana after cowpea, groundnut and bambara groundnut. The high protein content as well as the presence of the amino acid lysine makes them a suitable cheap source for fortification of cereal diets in most economies in transition [3]. Lima beans like all other legumes are food resources that offer various optimums nutritional and health benefits. The protein content of legume grains range from 17 to $40 \mathrm{~g} / 100 \mathrm{~g}$, much higher than that in cereals $(7-11.8 \mathrm{~g} / 100 \mathrm{~g})$ and approximately equal to the protein content of meat $18-25 \mathrm{~g} / 100 \mathrm{~g}$ [3].

Despite its promising nutrition composition, lima bean has been found by some researchers to contain anti-nutritional factors (ANFs) that could be injurious to the health of consumers [4]. However, these anti-nutritional constituent could be eliminated or reduced by some processing methods. For instance, Cooking inactivates or reduces the levels of 
anti-nutrients such as trypsin inhibitors and flatulencecausing oligosaccharides, resulting in improved nutritional quality [5]. It also renders legumes edible and ensures they have acceptable sensory properties [6]. Cooking time that gives an indication of cooking quality is one of the most important factors responsible for consumer's choice for a particular food. Of the major limitations that make lima bean like other legumes uneconomical and unacceptable to consumers is its longer cooking time. Besides cooking time, the assessment of texture is also critical to the determination of cooking quality and plays an important role in determining consumer acceptance of cooked legumes [7]. Some examples of cooking characteristics are: Cooking time, cooked lengthbreadth ratio, Water uptake ratio, Hydration capacity and hydration index, Swelling capacity and swelling index.

Apart from cooking characteristics, physical properties of seeds are also important for the design of equipment necessary for harvesting and post-harvest handling, transportation and processing of agricultural produce into different consumable and marketable food items [8]. A physical property is any property that is measurable whose value describes a state of a physical system. The changes in the physical properties of a system can be used to describe its transformations or evolutions between its momentary states. The physical properties of legumes mostly include Water uptake ratio, Length/breadth ratio, 1000-seed weight, Seed dimensions, Bulk density and true density. Various types of unit operations such as harvesting, threshing, cleaning, grinding, sorting, transportation and packaging are designed on the basis of the physical properties [9]. In order to combat food insecurity in Ghana and Africa as a whole, efforts are being made by the Crops Research Institute of the Council for Scientific and Industrial Research (CSIR), Ghana, to produce new bean varieties with improved characteristics such as high yield, disease resistance and high nutritional value. Some of the legume varieties under scientific investigations are the lima bean accessions. Hence, there are no documental records on their physical and cooking properties. This necessitated the research to evaluate the above two properties to make information available for farmers, consumers and food processors as a whole. Utilization of food usually depends on available information. Thus, the main purpose of the study was to evaluate the physical and cooking characteristics of 5 improved lima beans obtained from Crop Research Institute of Ghana.

The study was intended to achieve the following specific objectives: (i) to determine the physical properties of five accessions of lima bean and (ii) to evaluate the cooking characteristics of five improved lima bean.

\section{Materials and Methods}

\subsection{Materials}

Five improved lima beans (Phaseolus lunatus) accessions designated: Nkurakan black (NB01), Bososo cream black (BC02), Mampong white (MW03), Oseikrom cream (OsC04), and Ohwum Mampong cream brown (OMC05), were collected from Crop Research Institute (CSIR), Kumasi Fumesua Ghana. The beans were selected and cleaned manually. It was ensured that the seeds were free of dirt, broken and immature ones, and other foreign materials.

\subsection{Seed Dimensions}

Hundred randomly selected seeds were used to measure length (L), breadth (B) and thickness (T), three principal dimensions which are in the three mutually perpendicular directions using A Vernier caliper reading $0.01 \mathrm{~mm}$.

\subsubsection{0-Seed Weight}

1000 -seed weight was determined by counting one hundred seeds manually and weighing. The obtained values were then multiplied by a factor 10 to get 1000 -seed weight [10].

\subsubsection{Length/Breadth Ratio}

Ten (10) randomly selected seeds were observed for length/breadth ratio by simply dividing calculated length by calculated ratio of the 10 cooked seeds was determined by dividing the cumulative length to the cumulative breadth of cooked seeds.

\subsubsection{Water Uptake Ratio}

Thirty (30) grams of seeds was cooked in $400 \mathrm{ml}$ of double distilled water for minimum cooking time of 15 minutes at $60^{\circ} \mathrm{C}$. The cooked seeds were then removed; drained and surface water on seeds was removed by using filter paper. The samples were weighed and the water uptake ratio was calculated as the ratio of weight gained after cooking to weight before cooking.

\subsubsection{Bulk Density}

Bulk density was determined according to the method of [11] and expressed as $\mathrm{g} / \mathrm{L}$. The seeds were weighed before grinding and it was then weighed after grinding. The ground samples were measured in measuring cylinder.

\subsection{Cooking Time}

Cooking time was determined according to the method of [12]. The seeds were weighed and cooked at $65^{\circ} \mathrm{C}$ with $550 \mathrm{ml}$ of distilled water.

\subsubsection{Cooked Length-Breadth Ratio}

The cumulative length and breadth of 10 seeds were measured after cooking for minimum cooking time. The length-breadth ratio of the 10 cooked seeds was determined by dividing the cumulative length to the cumulative breadth of cooked seeds.

\subsubsection{Water Uptake Ratio}

Thirty (30) grams of seeds was cooked in $400 \mathrm{ml}$ of double distilled water for minimum cooking time of 15 minutes at $65^{\circ} \mathrm{C}$. The cooked seeds were then removed; drained and surface water on seeds was removed by using filter paper. The samples were weighed and the water uptake ratio was calculated as the ratio of weight gained after cooking to weight before cooking. 


\subsubsection{Hydration Capacity and Hydration Index}

Seeds $(10 \mathrm{~g})$ were soaked in $100 \mathrm{ml}$ of distilled water in a measuring cylinder and covered with an aluminum foil. The seeds were left to soak for $24 \mathrm{~h}$ in room temperature $\left(25^{\circ} \mathrm{C}\right)$; drained and excess water was removed using a tissue paper. The weight of the swollen seeds was measured. Hydration capacity and hydration index were calculated [13].

$$
\begin{gathered}
\text { Hydration capacity }=\frac{\text { Weight after soaking }- \text { Weight before soaking }}{\text { Number of seed }} \\
\text { Hydration index }=\frac{\text { Hydration capacity of seed }}{\text { Weight of one seed }}
\end{gathered}
$$

\subsubsection{Swelling Capacity and Swelling Index}

The volume of $5 \mathrm{~g}$ of seeds was predetermined using a graduated cylinder and they were subsequently soaked overnight in distilled water. The volume of the seeds after soaking was then measured. Swelling capacity and the swelling index were determined [13].

$$
\begin{gathered}
\text { Swelling capacity }=\frac{\text { Volume after soaking }- \text { Volume before soaking }}{\text { Number of seed }} \\
\text { Swelling index }=\frac{\text { Swelling capacity of seed }}{\text { Number of seed }}
\end{gathered}
$$

\subsection{Statistical Analysis}

The analysis of variance (ANOVA) procedures were used to analyze all data using the statistical package for social package for social sciences (SPSS) version 21 for window. Mean separation was performed by the LSD test. A level of $p$ $<0.05$ was used to indicate significant differences.

\section{Results and Discussions}

\subsection{Physical Properties of the Improved Lima Bean Seeds}

Knowledge of physical properties is imperative for the design of equipments which are used for processing of seeds in the industries which involves harvesting, threshing, cleaning, separation, transportation and packaging. Various physical parameters evaluated for different varieties of lima beans were seed length, breadth, thickness, thousand (1000) seed weight, length breadth ratio, water uptake ratio and bulk density.

Seed length ranged from $19.12 \mathrm{~mm}$ for MW03 to $25.50 \mathrm{~mm}$ for OMC05. With regard to seed breadth, accessions had values varying from $12.49 \mathrm{~mm}$ to $15.41 \mathrm{~mm}$. The lowest and highest breadths were found in MW03 and NB01. Values of seed thickness ranged from a minimum of $5.10 \mathrm{~mm}$ for NB01 to a maximum of $6.58 \mathrm{~mm}$ for OMC05 (table 1). There were significant differences among the accessions in relation to seed dimensions except seed thickness. The seed size, shapes and colors of the five accessions is depicted in appendix 1 . The results for seed dimensions are higher than those from [14] who have reported length, minor diameter and major diameter in the range of 7.73-7.67 mm, 4.51-4.86 mm, and $5.75-6.30 \mathrm{~mm}$, respectively. This means that lima beans if widely cultivated will make more food than cowpea which at long run will reduce food insecurity in the hunger threatened areas in Africa. The thousand (1000) seed weight differed significantly $(P<0.05)$ among all the five accessions with a range from $886.00 \mathrm{~g}$ for $\mathrm{MW} 03$ to $1311.65 \mathrm{~g}$ for $\mathrm{OMC} 05$ (table 1). The results are far higher than those reported by [14] for three cowpea cultivars with 1000-seed weight in the range of 131.6-151.6 g. Additionally, [15] have reported 1000 seed mass for certain cowpea seeds in the range between $140.44 \mathrm{~g}$ and $192.81 \mathrm{~g}$. The seed weight of lima bean variety could be a useful criterion for determining suitability for a particular end-use application. For example, varieties with large seeds would be preferred for canning, since this would mean less quantity of beans would be required to attain a high cooked bean weight. Furthermore, classification based on seed weight may be used to determine conformity to standards during quality control of raw materials. [16;17] identified five morphotypes of lima bean on the basis of hundred-seed weight, seed length, and seed width. These types include Big lima (100-110 g, $25 \mathrm{~mm}$ long, $14 \mathrm{~mm}$ wide), Sieva ( $30-45.3 \mathrm{~g}, 12 \mathrm{~mm}$ long, 8 wide), Potato ( $35.5 \mathrm{~g}, 9 \mathrm{~mm}$ long, $8 \mathrm{~mm}$ wide), Potato-Sieva (36.3 g, $11 \mathrm{~mm}$ long, $8 \mathrm{~mm}$ wide) and Sieva-Big (77.5 g, $17 \mathrm{~mm} \mathrm{long,}$ $11 \mathrm{~mm}$ wide). The dimensions of lima beans and their 1000seed weight give indication of the space the flour would occupy as well as their bulkiness. Since the dimensions and 1000 -seed weight of the five lima bean cultivars were significantly different, suggesting that equal quantity of each variety would occupy unequal space and the cost of packaging and transportation would be different if based on space occupied. 
Table 1. Seed dimensions and 1000-seed weight of the lima bean accessions.

\begin{tabular}{|c|c|c|c|c|}
\hline \multirow{2}{*}{ Names of varieties } & \multicolumn{3}{|c|}{ Mean seed size (mm) } & \multirow{2}{*}{ 1000-seed weight (Grams-g) } \\
\hline & Length (mm) & Breadth $(\mathrm{mm})$ & Thickness (mm) & \\
\hline NB01 & $23.36 \pm 0.1^{\mathrm{a}}$ & $15.41 \pm 0.1^{\mathrm{a}}$ & $5.10 \pm 0.0^{\mathrm{ab}}$ & $1124.95 \pm 1.6^{\mathrm{a}}$ \\
\hline $\mathrm{BC} 02$ & $20.72 \pm 0.1^{\mathrm{b}}$ & $13.98 \pm 0.1^{\mathrm{b}}$ & $5.73 \pm 0.0^{\mathrm{abc}}$ & $1169.05 \pm 2.2^{\mathrm{b}}$ \\
\hline MW03 & $19.12 \pm 0.0^{\mathrm{c}}$ & $12.41 \pm 0.1^{\mathrm{cd}}$ & $6.18 \pm 0.1^{\mathrm{abcd}}$ & $886.00 \pm 1.10^{c}$ \\
\hline $\mathrm{OsC} 04$ & $19.96 \pm 0.1^{\mathrm{d}}$ & $12.49 \pm 0.0^{\mathrm{d}}$ & $5.77 \pm 0.0^{\mathrm{abc}}$ & $973.95 \pm 3.3^{\mathrm{d}}$ \\
\hline OMC05 & $25.50 \pm 0.0^{\mathrm{e}}$ & $14.51 \pm 0.1^{\mathrm{e}}$ & $6.58 \pm 0.3^{\text {bcde }}$ & $1311.65 \pm 2.1^{\mathrm{e}}$ \\
\hline
\end{tabular}

Values in the same column having different superscripts are significantly different $(\mathrm{p}<0.05)$.

\subsection{Length-Breadth, Water Uptake Ratio and Bulk Density of the Lima Bean Seeds}

The results for the above parameters are presented in table 2. Length-breadth ratio varied from 1.49 for $\mathrm{BC} 02$ to 1.76 for OMC05. The water uptake ratio and bulk density was observed from $1.15-1.81 \mathrm{~g}$ and $0.59-0.62 \mathrm{~g} / \mathrm{ml}$, respectively. There were no statistically significant differences among the improved lima bean varieties. [14] have reported length, minor diameter and major diameter in the range of 7.73 $7.67 \mathrm{~mm}, 4.51-4.86 \mathrm{~mm}$, and $5.75-6.30 \mathrm{~mm}$, respectively for cowpea seeds.

Table 2. Length breadth ratio, water uptake ratio and bulk density of the lima bean seeds.

\begin{tabular}{llll}
\hline Names of varieties & Length breath ratio & Water uptake ratio (g) & Bulk density (g/ml) \\
\hline NB01 & $1.53 \pm 0.0^{\mathrm{abc}}$ & $1.15 \pm 0.0^{\mathrm{ab}}$ & $0.59 \pm 0.0^{\mathrm{a}}$ \\
$\mathrm{BC} 02$ & $1.49 \pm 0.0^{\mathrm{abc}}$ & $1.19 \pm 0.0^{\mathrm{ab}}$ & $0.62 \pm 0.0^{\mathrm{a}}$ \\
$\mathrm{MW03}$ & $1.54 \pm 0.0^{\mathrm{abc}}$ & $1.31 \pm 0.1^{\mathrm{a}}$ & $0.60 \pm 0.0^{\mathrm{a}}$ \\
OsC04 & $1.61 \pm 0.0^{\mathrm{bcde}}$ & $1.81 \pm 0.0^{\mathrm{ab}}$ & $0.60 \pm 0.0^{\mathrm{a}}$ \\
OMC05 & $1.76 \pm 0.0^{\mathrm{bcde}}$ & $1.37 \pm 0.1^{\mathrm{bcd}}$ & $0.60 \pm 0.0^{\mathrm{a}}$ \\
\hline
\end{tabular}

Values in the same column having different superscripts are significantly different $(\mathrm{p}<0.05)$.

\subsection{Cooking Characteristics of the Improved Lima Beans}

Cooking process is the combination of heating and hydration. Cooking characteristics of five improved lima beans were studied by measuring cooking time, cooked length-breadth ratio, water uptake ratio, hydration capacity, hydration index, swelling capacity and swelling index (Table 3 ). The cooking time for the five (5) accessions of lima beans was within the range of $81.00 \mathrm{mins}$ to $91.50 \mathrm{mins}$ with no significant difference except for $\mathrm{BC} 02$. These results are slightly higher than the results of [14] who reported cooking time of $57 \mathrm{~min}, 65 \mathrm{~min}$ and $84 \mathrm{~min}$ for three cowpea varieties viz Nhyira, Tona and Adom, respectively. Cooking renders legumes edible and ensures their acceptable sensory properties [6]. The environment in the field and in postharvest storage influenced cooking times of pulses [18]. A shorter cooking time means, the bean will cook faster while longer cooking time implies it will take bean longer time to cook. Short cooking time is desirable as it reduces duration, energy used in cooking as well as save labour cost.

Cooked length-breadth and water uptake ratio was within the minimum and maximum values of 1.39-1.78 and 1.151.37 , respectively. There was no statistical difference $(\mathrm{p}<0.05)$ among the accessions in terms of Cooked length-breadth and water uptake ratio. Hydration capacity and hydration index were observed from 18.98 to $23.05 \mathrm{~g} / \mathrm{seed}$ and 7.14 to $10.45 \mathrm{~g} / \mathrm{seed}$, respectively (Table 3 ). Again, the values obtained were not significant $(\mathrm{p}<0.05)$ except for OMC05 in relation to hydration capacity. [19] have reported hydration capacity of $0.03 \mathrm{~g} / \mathrm{seed}$ and hydration index of 0.9 for cowpea which shows lower values in comparison to lima bean varieties. Higher hydration capacity has positive correlation with swelling capacity. According to [20], hydration of grains is a process that consists of soaking them in water in order to increase their moisture content. Water binding capacity's data are useful for assessing the technological suitability of bean protein materials in food applications. High water binding capacity is attributed to lose structure of starch polymers whiles low values indicates the compactness of the structure [21]. Application of high temperatures during the hydration process, can increase, reduce or maintain the equilibrium moisture content without variation, temperatures higher than $60^{\circ} \mathrm{C}$ can drastically change the properties of grain compositions such as starch and proteins [22]. In the preparation of baked products, extruded snacks and mash, water-binding capacity is an important parameter to be considered.

Swelling capacity and swelling index of the five improved lima beans were in the range of $17.98-20.38 \mathrm{ml} / \mathrm{seed}$ and 3.30-5.10, respectively (Table 3 ). All the accessions showed no significant difference. [19] has reported swelling capacity and swelling index values as $0.053 \mathrm{~mL} /$ seed and 0.001 $\mathrm{mL} / \mathrm{seed}$, respectively for cowpea. Swelling capacity gives an indication of increase in the volume upon absorption of water. It is a very important parameter when changes in volume after processing enhance the acceptability of the final product. [23] reported that swelling power is a measure of hydration capacity, because the determination is a weight measure of swollen starch granules and their occluded water. Food eating quality is often connected with retention of water in the swollen starch granules. 
Table 3. Cooking characteristics of five improved lima bean.

\begin{tabular}{|c|c|c|c|c|c|}
\hline Parameter & NB01 & BC02 & MW03 & OsC04 & OMC05 \\
\hline Cooking time $(\mathrm{min})$ & $81.50 \pm 3.5^{\mathrm{ab}}$ & $91.50 \pm 2.1^{\mathrm{bc}}$ & $84.00 \pm 2.8^{\mathrm{ab}}$ & $83.00 \pm 4.2^{\mathrm{ab}}$ & $81.00 \pm 2.8^{\mathrm{ab}}$ \\
\hline Cooked length breadth ratio & $1.49 \pm 0.0^{\mathrm{a}}$ & $1.57 \pm 0.0^{\mathrm{a}}$ & $1.42 \pm 0.0^{\mathrm{a}}$ & $1.39 \pm 0.1^{\mathrm{a}}$ & $1.78 \pm 0.3^{\mathrm{a}}$ \\
\hline Water uptake ratio & $1.15 \pm 0.0^{\mathrm{ab}}$ & $1.19 \pm 0.0^{\mathrm{a}}$ & $1.31 \pm 0.1^{\mathrm{a}}$ & $1.18 \pm 0.0^{\mathrm{a}}$ & $1.37 \pm 0.1^{\mathrm{ab}}$ \\
\hline Hydration index & $7.14 \pm 1.0^{\mathrm{a}}$ & $8.65 \pm 0.4^{\mathrm{a}}$ & $10.08 \pm 2.7^{\mathrm{a}}$ & $10.45 \pm 3.1^{\mathrm{a}}$ & $9.52 \pm 3.7^{\mathrm{a}}$ \\
\hline Swelling capacity $(\mathrm{ml} / \mathrm{seed})$ & $19.40 \pm 2.0^{\mathrm{a}}$ & $19.63 \pm 1.2^{\mathrm{a}}$ & $18.04 \pm 0.9^{\mathrm{a}}$ & $17.98 \pm 0.3^{\mathrm{a}}$ & $20.38 \pm 3.0^{\mathrm{a}}$ \\
\hline Swelling index & $3.88 \pm 0.4^{\mathrm{a}}$ & $4.91 \pm 0.3^{\mathrm{ab}}$ & $3.30 \pm 0.3^{\mathrm{ab}}$ & $4.04 \pm 0.6^{\mathrm{a}}$ & $5.10 \pm 0.8^{\mathrm{ab}}$ \\
\hline
\end{tabular}

Values in the same column having different superscripts are significantly different $(\mathrm{p}<0.05)$.

\section{Conclusions}

The knowledge of physical and cooking properties of legumes is important because it provides as much data required for the design of various processing machines, processes and control in developing a new consumer product and in evaluating and retaining the quality of final products as well as very essential for the design of components of any machine. Seed length ranged from 19.12 to $25.50 \mathrm{~mm}$, breadth from 12.41 to $15.41 \mathrm{~mm}$ with significant differences among the accessions. However, thickness which varied from 5.10 to $6.58 \mathrm{~mm}$ showed no statistical significant difference. The thousand (1000) seed weight significantly varied from 886.00 to $1311.65 \mathrm{~g}$. All the five lima bean accessions belonged to the Andean gene pool or Meso-American large seeded type. Length/breadth \& water uptake ratio, and bulk density were within the range of 1.49 to $1.76,1.15$ to $1.81 \mathrm{~g}$, and 0.59 to $0.62 \mathrm{~g} / \mathrm{ml}$, respectively. The cooking time of all the accessions ranged from 81.00 to $91.50 \mathrm{mins}$ with no significant differences. Cooked Length-Breadth and water uptake ratios had minimum and maximum values of 1.39 to 1.78 and 1.15 to 1.31 , respectively. Seed hydration capacity and index had values between 18.98-23.05 g/seed\& 7.1410.45; swelling capacity ranged between $17.98-20.38 \mathrm{ml} / \mathrm{seed}$ and swelling index recorded values between 3.88-5.10. All the accessions had higher cooking time in comparison with some cowpea varieties grown in Ghana. The higher hydration and swelling capacity of the improved lima beans make them useful in food products that require much water.

\section{Recommendation}

1. Since, Lima beans take longer time to cook; it is recommended that a study be carried out to look at the effect of longer cooking on the nutritional composition of the lima beans.

2. Finally, the greatest impediment to utilizing underutilized legumes as a food and feed is the presence of anti-nutrients. It is therefore imperative to do further experiment to assess the quality and quantity of anti-nutrients.

\section{References}

[1] MacDonald L and J. Low (1984). Fruit and Vegetables. Evans Brothers, London, 137pp.
[2] Aletor, V. A. \& O. O. Aladetimi (1989). "Compositional Evaluation of Some Cowpea Varieties and Some Under Utilized Edible Legumes in Nigeria”. Die Nahrung 33 (1989) 10: 999-1007.

[3] Kaur, S., Singh, N., Sodhi, N. S., and Rana, J. C. (2009). Diversity in properties of seed and flour of kidney bean germplasm. Food Chemistry, 117, 282-289.

[4] Adeparusi, E. O and Ajayi, A. D. (Adeparusi 1999). Among the several methods used in assessing protein quality in feed, blood evaluation is rarely used.

[5] Wang, N., Hatcher, D. W., Gawalko, E. J., (2008). Effect of variety and processing on nutrients and certain anti-nutrients in field peas (Pisumsativum). Food Chem. 111, 132-138.

[6] Bourne, M. C. (1982). Food texture and viscosity. Concept and measurement. Academic Press Inc, New York. Chandrashaker, U., Lalitha, B., Rajamal-Devadas, P., 1981. Evaluation of protein quality of raw, roasted and autoclaved legumes supplemented with sulphur-containing amino acids. Indian J. Nutr. Diet. 18, 283-288.

[7] Stanley, D. W., Wu, X., Plhak, L. C., 1989. Seed coat effects in cooked reconstituted bean texture. J. Texture Stud. 20, 419-429.

[8] Hamid, S., Muzaffar, S., Wani, I. A., Masoodi, F. A., Bhat, M. M. (2014). Physical and cooking characteristics of two cowpea cultivars grown in temperate Indian climate. Journal of the Saudi Society of Agricultural Sciences. doi: 10.1016/j.jssas.2014.08.002.

[9] Yalcin, I. and Orzarslan, C. (2004). Physical properties of vetah seed. Journal of Biosystem Engineering, 88 (4), pp 507512.

[10] AACC (2000). Approved methods of the AACC international. Methods 44-15A, 56-35, 76 13, and 08-16 (tenth ed.). St. Paul, MN: The Association.

[11] Wani, I. A., Sogi, D. S., Gill, B. S., (2013a). Physicochemical and functional properties of flours from three Black gram (Phaseolus mungo L.) cultivars. Int. J. Food Sci. Technol. 48, 771-777.

[12] Wani, I. A., Sogi, D. S., Gill, B. S., (2013b). Physical and cooking characteristics of black gram (Phaseolus mungoo L.) cultivars grown in India. Int. J. Food Sci. Technol. 48, 2557-2563.

[13] Adebowale, Y. A., Adeyemi, A. and Oshodi, A. A. (2005). Variability in physicochemical and antinutritional attributes of six Mucuna species. Food Chem. 89: 37-48.

[14] Appiah, F., Asibuo, J. Y. and Kumah, P. (2011). Physicochemical and functional properties of bean flours of three cowpea (VignaunguiculataL. Walp) varieties in Ghana. Afr. J. Food Sci. 5: 100-104. 
[15] Sobukola, O. P., Abayomi, H. T., 2011. Physical properties and rehydration characteristics of different varieties of maize (Zea mays L.) and cowpea (Vigna unguiculata (L.) Walp) Seed. J. Food Process. Preserv. 35 (3), 299-307.

[16] Lioi, L. (1994). Morphotype relationships in lima bean (Phaseolus lunatus L.) deduced from variation of the evolutionary marker phaseolin. Genet. Resour. Crop Evol. 41: 81-85.

[17] Esquivel, M., Castineiras, L. and Hammer, K. (1990). Origin, classification, variation and distribution of Limalima bean (Phaseolus lunatus L.) in the light of Cuban material. Euphytica 49: 89-97. Esquivel, M., Castiñeiras, L., Lioi, L.

[18] Berry, M., Wiesinger, J., Nchimbi -Msolla, S., Miklas, P., Porch, T., Fourie, D., and Cichy, K. (2016). Breeding for a fast cooking bean: A study of geno-types across environments to determine stability of the cooking time trait in Phaseolus vulgaris Bean Improvement Cooperative, Annual Report, 3334.
[19] Tresina, P. S., Mohan, V. R., (2012). Physico-chemical and anti-nutritional attributes of gamma irradiated Vignaunguiculata L. subsp. unguiculata seeds. Int. Food Res. J. 19 (2), 639-646.

[20] Miano, A. C and Augusto, P. E. D (2018). The Hydration of Grains: A Critical Review from Description of Phenomena to Process Improvements. Comprehensive Reviews in Food Science and Food Safety https://doi.org/10.1111/15414337.12328

[21] Nwokocha, L. M. and Peter, A. W. (2011). Carbohydrate Polymers. 84: 395-401.

[22] Fracasso A. F, Frizon C. N. T, de Matos Jorge L. M, Jorge R. M. M. (2015). Hydration kinetics of transgenic soybeans. Acta Sci-Technol 37: 141-7.

[23] Sreerama, Y. N., Sashikala, V. B., Pratape, V. M., and Singh, V. (2012). Nutrients and antinutrients in cowpea and horse gram flours in comparison to chickpea flour: evaluation of their flour functionality. Food Chemistry, 131, 462-468. 